\title{
Perbedaan Kadar Lisozim dalam Air Susu Ibu (ASI) pada Bayi Sehat dan Bayi Sakit yang Mendapat ASI Eksklusif
}

\author{
Irwandi, ${ }^{*}$ Gustina lubis, ${ }^{*}$ Nur Indrawati Lipoeto** \\ *Departemen Ilmu Kesehatan Anak Fakultas kedokteran Universitas Andalas/RSUP dr.M. Djamil Padang \\ **Pasca sarjana Ilmu Biomedik Fakultas Kedokteran Universitas Andalas
}

\begin{abstract}
Latar belakang. Air susu ibu (ASI) sangat diperlukan selama masa pertumbuhan dan perkembangan bayi untuk meningkatkan daya tahan tubuh karena mengandung anti mikroba seperti lisozim. Air Susu Ibu mengandung 300 kali lebih banyak lisozim dibandingkan susu sapi. Lisozim berperan sebagai sistem imunitas alami yang dapat melindungi bayi dari berbagai macam infeksi.

Tujuan. Mengetahui perbedaan kadar lisozim dalam ASI pada bayi sehat dan bayi sakit yang mendapat ASI eksklusif.

Metode. Penelitian ini menggunakan desain potong lintang komparatif, dilakukan pada September-November 2016 di beberapa Puskesmas di kota Padang dan RSUP Dr M Djamil Padang.

Hasil. Lisozim lebih tinggi dalam ASI di kelompok bayi sakit dibandingkan ASI di kelompok bayi sehat, tetapi perbedaannya tidak bermakna ( $p$,183). Lisozim lebih tinggi dalam ASI di kelompok bayi yang menderita infeksi saluran nafas dibandingkan dengan bayi yang menderita infeksi saluran cerna.

Kesimpulan. Terdapat perbedaan kadar lisozim dalam ASI pada bayi sehat dan bayi sakit yang mendapat ASI eksklusif, tetapi secara statistik perbedaannya tidak bermakna. Sari Pediatri 2018;19(5):273-8
\end{abstract}

Kata kunci: lisozim, ASI, bayi sehat, bayi sakit

\section{Difference of Lysozyme Levels on Human Milk Between Healthy and Sick Infant who had Exclusively Breast Fed Infant}

Irwandi, ${ }^{*}$ Gustina lubis, ${ }^{*}$ Indrawati Lipoeto**

Background. Human milk contains antimicrobial such as lysozyme which very important during infant growth and development and will improve immunity. Human milk contains more lysozyme than cow's milk. Lysozyme plays role as natural immunity, which can protect an infant from multiple infections.

Objective. Knowing the difference levels of lysozym from human milk on healthy and sick infant who had exclusive breast fed infant Methods. This study uses a comparative cross-sectional design, conducted in September- November 2016 at several health centers in the city of Padang and Dr M Djamil Padang

Result. Lysozyme is higher in the group of sick infant than in group healthy infant, but not significant (p 0.183). Lysozyme is higher in infants who had respiratory infections than in infants who had gastrointestinal infections

Conclusion. There is the difference of lysozyme levels in human milk of healthy and a sick infant who had exclusively human milk, but statistically not significant. Sari Pediatrí 2018;19(5):273-8

Keywords: lysozyme, human milk, healthy infant, sick infant

Alamat korespondensi: Dr. Irwandi. Departemen Ilmu Kesehatan Anak FK-UNAND/ RSUP dr.M.Djamil Jl.Perintis Kemerdekaan. Padang, Sumatera Barat. Email: innandi23@gmail.com 
A

ir susu ibu eksklusif diberikan kepada bayi sejak dilahirkan sampai usia enam bulan, tanpa menambahkan dan/atau mengganti dengan makanan atau minuman lain. ${ }^{1}$ Air susu ibu merupakan suatu cairan kompleks dengan sejumlah besar protein, sel, dan komponen lainnya. Pengaruh imunologis berhubungan dengan kenyataan bahwa ASI kaya dengan berbagai faktor aktif, khususnya antibodi seperti lisozim, laktoferin, dan imunoglobulin A sekretoris (SIgA). Di samping itu, ASI juga terbukti dapat mengurangi kejadian infeksi terhadap gastroenteritis, infeksi saluran pernafasan, otitis media, sepsis neonatorum dan infeksi saluran kemih. World Health Organization (WHO) melaporkan bahwa $40 \%$ kematian bayi di negara berkembang disebabkan diare dan infeksi saluran pernapasan akut. Hal ini dapat dicegah dengan ASI eksklusif. ${ }^{2-4}$

Data dari National Immunization Survey di Amerika pada tahun 2004, 70,3\% ibu pernah menyusui, 36,2\% ibu melanjutkan sampai bulan ke-6, $38,5 \%$ ibu menyusui eksklusif sampai bulan ke-3, dan $14,1 \%$ ibu menyusui eksklusif sampai bulan ke-6. ${ }^{5}$ Riset Kesehatan Dasar 2013 (Riskesdas 2013) melaporkan peningkatan cakupan pemberian ASI eksklusif dari 15,3\% tahun 2010 menjadi 30,2\% tahun 2013, dan inisiasi menyusui dini $<1$ jam meningkat dari 29,3\% tahun 2010 menjadi $34,5 \%$ tahun $2013 .^{6}$

Diare dan infeksi saluran nafas sampai saat ini masih menjadi masalah kesehatan masyarakat di dunia, terutama negara berkembang termasuk Indonesia, dan merupakan salah satu penyebab morbiditas dan mortalitas tertinggi pada anak usia balita. Berdasarkan Riskesdas 2013 didapatkan 6,7\% insiden diare balita di Indonesia turun dibandingkan Riskesdas 2007, sedangkan kelompok tertinggi penderita diare terjadi pada kelompok umur $<1$ tahun $(7 \%)$. Insiden pneumonia balita di Sumatera Barat meningkat 18,5\%. Insiden diare balita di Sumatera Barat lebih tinggi dari rerata nasional $(7,1 \%)$, tetapi insiden pneumonia masih di bawah rerata nasional $(10,2 \%)$. $^{6-7}$

Lisozim merupakan suatu enzim yang diproduksi oleh makrofag, neutrofil, dan epitel kelenjar payudara, dapat memecah dinding sel bakteri yang ada pada mukosa usus dan menambah aktifitas bakterisid imunoglobulin A sekretoris SIgA. Lisozim juga merupakan salah satu faktor yang dapat memengaruhi mikroflora usus bayi. ${ }^{2,8}$ Lisozim dalam satuan volume yang sama pada ASI mengandung 300 kali lebih banyak dibandingkan susu sapi. Aktivitas antimikroba lisozim yang terdapat dalam cairan tubuh telah dibuktikan secara in vitro. ${ }^{9,10}$

Beberapa penelitian telah mencoba mencari hubungan kadar lisozim dan komponen immunoglobulin dalam ASI dengan kejadian sakit pada bayi. Studi Ella dkk $^{11}$ di Nigeria didapatkan peningkatan yang cepat kadar SIgA dan lisozim dalam ASI ibu yang menyusui bayi sakit. Hal ini diduga terjadi karena stimulasi respon imun ibu secara tidak langsung terhadap infeksi yang terjadi pada bayi. Penelitian Hassiotou dkk ${ }^{12}$ di Australia menjelaskan bahwa saat bayi sakit, hubungan ibu dan bayinya terutama saat menyusui akan merangsang respon imun ibu, dan akan meningkatkan jumlah leukosit dalam ASI untuk mempercepat penyembuhan bayi yang terinfeksi. ${ }^{12}$ Tujuan penelitian ini adalah untuk mengetahui perbedaan kadar lisozim dalam ASI eksklusif antara bayi sehat dan bayi sakit

\section{Metode}

Digunakan desain potong lintang komparatif (comparative cross sectional). Penelitian dilakukan di bagian Ilmu Kesehatan Anak RSUP DR. M. Djamil, lingkungan kerja Puskesmas di kota Padang, dan Laboratorium Biomedik Fakultas Kedokteran Universitas Andalas.

Populasi adalah ibu dan bayi yang mendapatkan ASI eksklusif. Sampel adalah bayi usia 3-6 bulan yang mendapatkan ASI eksklusif dan memenuhi kriteria inklusi penelitian. Pemilihan sampel dilakukan secara consecutive sampling. Berdasarkan perhitungan jumlah sampel didapatkan minimal jumlah sampel 25 untuk masing-masing kelompok penelitian.

Kriteria inklusi pada kelompok bayi sehat adalah bayi berusia 3-6 bulan yang masih mendapat ASI eksklusif, lahir cukup bulan, orang tua bersedia mengikuti penelitian dengan mengisi lembar persetujuan (informed consent). Kriteria inklusi pada kelompok bayi sakit adalah bayi berusia 3-6 bulan yang masih mendapat ASI eksklusif dan saat diperiksa dalam keadaan sakit (menderita infeksi saluran nafas dan saluran cerna). Orang tua bersedia mengikuti penelitian dengan mengisi lembar persetujuan (informed consent). Kriteria eksklusi adalah ibu yang telah dikenal menderita defisiensi imun, infeksi akut, atau infeksi kronik seperti tuberkulosis, bayi yang menderita sakit infeksi selain infeksi saluran nafas atau saluran cerna, bayi yang sudah dikenal menderita kelainan kongenital yang memengaruhi kekerapan 
sakit, seperti penyakit jantung bawaan dan defisiensi hormon seperti hipotiroid kongenital. Penelitian ini telah mendapat izin dari komite etik FK Unand, Padang.

Metode analisis data yang digunakan adalah analisis deskriptif dan uji t sederhana untuk data tidak berpasangan dengan distribusi data yang normal atau uji Mann-Whitney untuk data yang tidak terdistribusi normal. Analisis deskriptif digunakan untuk menggambarkan karakteristik sampel. Uji t atau Mann-Whitney digunakan untuk mengetahui perbedaan kadar lisozim ASI pada bayi sehat dan bayi sakit dan dianggap bermakna bila $\mathrm{p}<0,05$. Data diolah dengan menggunakan program SPSS versi 15

\section{Hasil}

Didapat 65 subyek penelitian yang kemudian dibagi ke dalam 2 kelompok, yaitu kelompok bayi sehat berjumlah 30 dan kelompok bayi sakit berjumlah 35 . Karakterisitik subyek penelitian tertera pada Tabel 1.

Jenis infeksi terbanyak pada kelompok bayi sakit adalah infeksi saluran nafas $(62,86 \%)$. Rerata umur ibu pada kelompok bayi sakit lebih tinggi dari kelompok bayi sehat. Berat badan ibu pada kelompok bayi sehat lebih tinggi dari kelompok bayi sakit.

Kadar lisozim ASI di kedua kelompok tertera pada Tabel 2. Pada setiap kelompok terdapat beberapa nilai ekstrim kadar lisozim. Nilai ekstrim ini menunjukkan distribusi data yang tidak normal yang dibuktikan dengan uji Kolmogorov-Smirnov $(\mathrm{p}<0,05)$ sehingga data kadar lisozim yang ditampilkan berupa median bukan rerata, dan untuk uji kemaknaan digunakan uji Mann-Whitney. Kadar lisozim di kelompok bayi sakit lebih tinggi dari kelompok bayi sehat. Berdasarkan analisis statistik tidak terdapat perbedaan kadar lisozim antara bayi sehat dan sakit $(\mathrm{p}>0,05)$.

Kadar lisozim ASI antara bayi yang menderita infeksi saluran nafas dan infeksi saluran cerna tertera pada Tabel 2. Pada setiap kelompok juga terdapat beberapa nilai ekstrim kadar lisozim, nilai ekstrim ini menunjukkan distribusi data yang tidak normal yang dibuktikan dengan uji Kolmogorov-Smirnov $(\mathrm{p}<0,05)$ sehingga data kadar lisozim yang ditampilkan berupa median bukan rerata, dan untuk uji kemaknaan digunakan uji Mann-Whitney. Kadar lisozim pada bayi yang menderita infeksi saluran cerna lebih tinggi dibandingkan dengan infeksi saluran nafas. Berdasarkan analisis statistik tidak terdapat perbedaan antar kelompok ( $>>0,05)$.

\section{Pembahasan}

Jumlah sampel infeksi saluran nafas lebih banyak dari pada infeksi saluran cerna. Berdasarkan Riskesdas 2013, period prevalence kejadian infeksi saluran nafas lebih banyak dibandingkan kejadian diare $(25 \%$ vs

Tabel 1. Karakteristik sampel penelitian

\begin{tabular}{|c|c|c|c|}
\hline Karakteristik & Bayi sehat $(\mathrm{n}=30)$ & Bayi sakit $(\mathrm{n}=35)$ & Nilai p \\
\hline $\begin{array}{l}\text { Jenis kelamin, } \mathrm{n}(\%) \\
\text { Laki-laki } \\
\text { Perempuan }\end{array}$ & $\begin{array}{c}18(50) \\
12(41,4)\end{array}$ & $\begin{array}{c}18(50) \\
17(58,6)\end{array}$ & $0,618^{*}$ \\
\hline Usia (bulan), median (min-max) & $5(3-6)$ & $5(3-6)$ & $0,774^{* *}$ \\
\hline $\begin{array}{l}\text { Antropometri } \\
\text { Berat badan lahir, rerata(SD), gram } \\
\text { Berat badan diperiksa, rerata(SD), gram } \\
\text { Panjang badan, rerata(SD), cm }\end{array}$ & $\begin{array}{c}3173,33(418,27) \\
6973(813,82) \\
64,08(3,47)\end{array}$ & $\begin{array}{c}3151,42(395,83) \\
6737,86(1069,28) \\
63,26(4,33)\end{array}$ & $\begin{array}{l}0,83^{* * *} \\
0,319^{* * *} \\
0,399^{* * *}\end{array}$ \\
\hline $\begin{array}{l}\text { Jenis infeksi bayi } \\
\text { Infeksi saluran nafas (\%) } \\
\text { Infeksi saluran cerna (\%) }\end{array}$ & & $\begin{array}{l}22(62,86) \\
13(37,14)\end{array}$ & \\
\hline $\begin{array}{l}\text { Data ibu } \\
\text { Umur ibu, median (min-max),tahun } \\
\text { Berat badan ibu, median (min-max), kg }\end{array}$ & $\begin{array}{c}29(26-55) \\
54,5(48-79)\end{array}$ & $\begin{array}{l}30(19-37) \\
54(37-85)\end{array}$ & $\begin{array}{l}0,706^{* *} \\
0,147^{* *}\end{array}$ \\
\hline
\end{tabular}


Irwandi dkk: Perbedaan kadar lisozim ASI pada bayi sehat dan bayi sakit yang mendapat ASI eksklusif

Tabel 2. Perbedaan kadar lisozim di ASI

\begin{tabular}{|c|c|c|c|}
\hline Kelompok bayi & $\mathrm{N}$ & $\begin{array}{l}\text { Median (minimum-maksimum) } \\
(\mathrm{ng} / \mathrm{ml})\end{array}$ & Nilai $p$ \\
\hline \multicolumn{4}{|c|}{ Bayi sehat dan sakit $(\mathrm{n}=65)$} \\
\hline Sehat & 30 & $1,019(0,780-2,871)$ & $0,183^{*}$ \\
\hline Sakit & 35 & $1,044(0,803-3,358)$ & \\
\hline \multicolumn{4}{|l|}{ Infeksi $(\mathrm{n}=35)$} \\
\hline Saluran nafas & 22 & $1.007(0,803-3.358)$ & $0,104^{*}$ \\
\hline Sakuran cerna & 13 & $1,291(0,827-3.127)$ & \\
\hline
\end{tabular}

*Uji Mann-Whitney

3,5-7\%). Penurunan dibandingkan data Riskedas 2007 disebabkan angka cakupan ASI eksklusif di Indonesia juga meningkat. ${ }^{6}$ Hal tersebut membuktikan bahwa pemberian ASI eksklusif terbukti dapat megurangi risiko infeksi pada bayi. Pemberian ASI dengan berbagai kandungan uniknya yang diberikan secara eksklusif telah terbukti dapat mengoptimalkan fungsi saluran cerna dan mencegah kejadian diare akut. ${ }^{13}$

Alarcon $\mathrm{dkk}^{14}$ melaporkan kejadian ISPA pada bayi yang mendapat ASI eksklusif lebih banyak dibandingkan kejadian diare. Namun, kejadian tersebut jauh lebih rendah dibandingkan dengan bayi yang mendapatkan susu formula. Hasil Penelitian ini hampir sama dengan penelitian Howie $\mathrm{dkk}^{15}$ terhadap bayi yang mendapatkan ASI, dan ditindaklanjuti pada risiko menderita diare, ISPA, infeksi mulut, telinga, mata dan kulit. Terlihat bahwa ISPA merupakan penyakit paling sering diderita bayi yang mendapat ASI eksklusif, diikuti oleh diare, infeksi mata, infeksi mulut, infeksi kulit, dan infeksi telinga. Penelitian Lamberti $\mathrm{dkk}^{16}$ yang dilakukan di negara berkembang seperti Amerika Latin, Afrika, Asia Selatan, Pasifik Barat, dan Timur Tengah, didapatkan bahwa risk ratio insiden diare bayi $0-5$ bulan yang tidak mendapat ASI eksklusif adalah 2,65. Sebaliknya pada bayi yang mendapat ASI eksklusif adalah 1,26.

Pola menyusu eksklusif pada bayi usia $0-5$ bulan berdasarkan usia terus menurun dari 39,8\% pada 0 bulan menjadi $15,3 \%$ pada 5 bulan. Di samping itu, cakupan pemberian ASI eksklusif pada bayi 0-6 bulan juga masih berfluktuasi, dari $32 \%$ pada 2007 menjadi $42 \%$ pada $2012 .{ }^{17}$ Pada penelitian ini, rerata usia bayi yang menjadi sampel adalah 5 bulan, menunjukkan bahwa cakupan ASI eksklusif cukup tinggi. Pada tahun 2014 rerata cakupan ASI eksklusif di Indonesia, Sumatera Barat dan target program 2014 adalah $52,3 \%, 73,6 \%$, dan $80 \% .{ }^{17}$ Sementara itu, di tahun sebelumnya atau di tahun 2013, rerata cakupan ASI eksklusif di Indonesia, Sumatera Barat, dan target program 2013 adalah 54,3\%, 68,9\%, dan 75\%. Secara keseluruhan berdasarkan Riskesdas 2013 terjadi peningkatan cakupan pemberian ASI eksklusif dari 15,3\% tahun 2010 menjadi 30,2\% tahun $2013 .^{6,17}$

Pada penelitian ini sampel ASI diperah sendiri oleh masing-masing ibu dan apabila dibutuhkan dapat dibantu oleh petugas. Pengambilan sampel ASI diupayakan antara jam 9 pagi sampai jam 11 siang agar didapatkan kandungan dalam ASI yang optimal. ${ }^{15}$ Sampel ASI selanjutnya dimasukkan dalam plastik ASI steril dan disimpan dilemari pendingin dengan suhu $-20^{\circ} \mathrm{C}$. Pemeriksaan kadar lisozim sampel dilakukan secara bersamaan.

Penyimpanan ini bertujuan untuk menjaga agar sampel tidak rusak dan kadar lisozim tidak berubah sebelum diperiksa. Menurut Lawrence, ${ }^{18}$ penyimpanan ASI pada suhu $-20^{\circ} \mathrm{C}$ sampai tiga bulan tidak menurunkan kadar protein dalam ASI secara bermakna. Penelitian lain menyebutkan kondisi yang sebaliknya. Arthur $\mathrm{dkk}^{19}$ menjelaskan bahwa penyimpanan ASI pada suhu $-18^{\circ} \mathrm{C}$ sampai $-20^{\circ} \mathrm{C}$ pada waktu 3-6 bulan akan memengaruhi kadar zat imunologis terutama laktoferin, SIgA dan lisozim.

Pada penelitian ini didapatkan rentang kadar lisozim pada bayi sehat berkisar dari rentang 0,78 $2,871 \mathrm{ng} / \mathrm{ml}$ dengan median $1,019 \mathrm{ng} / \mathrm{ml}$, sedangkan pada bayi sakit berkisar dari 0,803-3,358 ng/ml dengan median 1,044. Kadar lisozim dalam ASI bervariasi cukup besar, terlihat dari data yang tidak terdistribusi normal. Pada beberapa penelitian disebutkan rerata konsentrasi lisozim dalam ASI yang telah dilaporkan mulai dari $0,03 \mathrm{~g} / \mathrm{L}$ sampai 3,0 g/L. Variasi ini terjadi karena adanya perbedaan metodologi penelitian, seperti populasi penelitian (misalnya, 
Afrika, Eropa Barat, Amerika Serikat) dan metode analisis. Metode analisis yang digunakan, antara lain, uji aktivitas antimikroba, seperti Micrococcus lysodeikticus assay, immunoassay yang mendeteksi protein lisozim (seperti ELISA, immunoelectrophoresis/ difusi) atau elektroforesis (seperti SDS-PAGE). Kadar lisozim meningkat dalam 12 minggu setelah persalinan dan relatif konstan dalam ASI dalam 6-24 bulan setelah melahirkan. ${ }^{5}$ Lisozim ditemukan dalam jumlah yang besar dalam ASI bayi yang menyusu ASI. ${ }^{5,20}$ Terdapat 3 fase perubahan konsentrasi lisozim dalam ASI. Pertama fase inisial yaitu beberapa hari setalah melahirkan saat terjadi penurunan konsentrasi lisozim. Kedua fase stabilisasi, yaitu beberapa minggu setalah melahirkan saat konsentrasi lisozim kembali stabil. Ketiga fase akhir, saat konsentrasi mencapai puncaknya pada periode akhir laktasi. ${ }^{5}$

Pada penelitian ini rata-rata kadar SIgA lisozim dalam ASI ibu dengan anak yang sakit lebih tinggi dibanding dengan ibu dengan anak yang sehat, tetapi tidak berbeda secara bermakna. Sesuai dengan penelitian sebelumnya, Ella dkk ${ }^{11}$ melaporkan interaksi antara sIgA, laktoferin, dan lisozim dalam ASI pada ibu menyusui dengan anak sehat dan anak sakit.

Pada penelitian ini sampel dibagi menjadi 2 kelompok, yaitu kelompok ibu dengan bayi yang dirawat dengan sepsis, dan kelompok ibu dengan bayi yang sehat. Didapatkan 185 sampel ASI dari ibu dengan bayi yang sakit dan 193 sampel ASI dari ibu dengan bayi yang sehat. Hasil pemeriksaan SIgA dan lisozim pada ASI dari bayi sakit lebih tinggi dibandingkan bayi sehat. Peningkatan lisozim dalam ASI pada bayi sakit berkorelasi dengan peningkatan kadar sIgA, tetapi tidak terdapat korelasi antara lisozim dengan laktoferin. Pada bayi sakit yang mengalami sepsis, kecenderungannya adalah terjadi peningkatan kadar SIgA dan lisozim dengan cepat, diikuti dengan penurunan bertahap dari laktoferin. Ketika sudah terjadi sakit, maka SIgA akan cepat meningkat sebagai respon terhadap stimulasi imun terhadap ibu karena adanya infeksi atau faktor risiko pada bayi. Selain itu, terdapat hubungan erat antara SIgA dengan lisozim, sehingga lisozim ikut meningkat. Kondisi ini akan memuncak dan memberikan proteksi kepada bayi sehingga infeksi pada bayi menjadi lebih ringan. Ketika sudah sehat, SIgA akan menurun, sementara kadar lisozim tetap tinggi dan laktoferin mulai meningkat. Pada kondisi ini, peran sIgA mulai diambil alih oleh lisozim yang memiliki aktivitas enzimatik antibakterial berspektrum luas. ${ }^{11}$
Sampai saat ini mekanisme yang menerangkan fenomena terjadinya peningkatan lisozim ASI pada bayi sakit masih belum jelas. Beberapa penelitian mencoba menjelaskan fenomena ini. Riskin $\mathrm{dkk}^{21}$ melaporkan terjadinya peningkatan respon inflamasi pada tubuh ibu yang menyusui bayi sakit. Infeksi saluran nafas atau saluran cerna pada bayi yang menyusui juga akan menginfeksi ibu, karena adanya bonding antara ibu dan bayi walaupun tidak menimbulkan gejala pada ibu. Terdapat peningkatan kadar leukosit dan sitokin inflamasi dalam ASI yang diproduksi ibu yang memiliki bayi sakit. Hipotesis ini juga didukung oleh data yang menunjukkan 35\% ibu dan 65\% saudara kandung dari bayi sakit juga menderita demam. Hasil penelitian ini juga serupa dengan hasil penelitian Hassiotou $\mathrm{dkk}^{12}$ yang melaporkan terjadinya peningkatan kadar leukosit dan sel inflamasi pada ASI ibu yang memiliki bayi sakit. ${ }^{12}$

Kadar lisozim ditemukan lebih tinggi pada ASI bayi yang menderita infeksi saluran cerna dibandingkan ASI bayi yang menderita infeksi saluran nafas walaupun secara statistik tidak berbeda secara bermakna. Lisozim berperan dalam melawan patogen dalam saluran gastrointestinal dan menurunkan penyakit gastrointestinal pada bayi menyusui. Secara invitro, lisozim memiliki aktivitas terhadap beberapa patogen pencernaan, termasuk Listeria monocytogenesdan Clostridium perfringens. Bayi menyusui memiliki flora bakteri komensal yang sehat di saluran cerna. Studi menunjukkan bahwa flora usus normal pada bayi yang menyusui menjadi bakteri yang bersifat protektif terhadap penyakit pencernaan dan dapat menyebabkan pengembangan dan pematangan saluran usus. Penelitian invitro membuktikan lisozim dalam susu kambing memilki efek antimikroba terutama terhadap bakteri usus E.coli. ${ }^{22}$ Secara teori, lisozim memiliki efek bakterisid dan bakteriostatik terhadap semua mikroba, termasuk bakteri, virus, jamur, dan amuba. Secara invitro lisozim dapat menghidrolisis komponen dinding sel bakteri Gram positif tertentu, yang menyebabkan lisis terhadap sel sehingga akan mematikan bakteri tersebut (bakterisid). Efek bakterisid lisozim lebih mudah tercapai terhadap bakteri Gram positif dibandingkan Gram negatif karena membran luar bakteri Gram negatif terlindung oleh lipopolisakarida (LPS) yang berfungsi sebagai barrier untuk mencegah masuknya lisozim ke dalam peptidoglikan bakteri. ${ }^{23}$ Salah satu kelemahan dalam penelitian ini adalah tidak dilakukannya pemeriksaan kadar lisozim segera setelah dikumpulkan dan tidak dilakukan identifikasi spesifik apakah kuman penyebab infeksi yang diderita 
bayi sehingga sulit menjelaskan kenapa kadar lisozim ASI pada bayi yang menderita diare lebih tinggi dibandingkan bayi yang menderita ISPA.

\section{Kesimpulan}

Rerata kadar lisozim ASI cenderung lebih tinggi pada bayi sakit dibandingkan bayi sehat, tetapi tidak terdapat perbedaan yang bermakna antara kedua kelompok. Rerata kadar lisozim ASI pada bayi yang menderita infeksi saluran cerna cenderung lebih tinggi dari pada bayi yang menderita infeksi saluran nafas, tetapi tidak terdapat perbedaan yang bermakna secara statistik antara kedua kelompok. Disarankan untuk melakukan pemeriksaan sampel secara ELISA segera setelah pengambilan sampel, melakukan pemeriksaan kuman penyebab infeksi, serta harus tetap memberikan ASI walaupun bayi dalam keadaan sakit.

\section{Daftar pustaka}

1. Presiden Republik Indonesia. Peraturan pemerintah republik Indonesia nomor 23 tahun 2012 tentang pemberian air susu ibu eksklusif. Kemenkumham RI. Diunduh pada 26 Mei 2016. Didapat dari: http//www.kemenpppa.go.id/jdih/peraturan/ PP\%2033\%20thn\%202012.pdf.

2. Aldy OS, Lubis BM, Sianturi P, Azlin E, Tjipta GD. Dampak proteksi air susu ibu terhadap infeksi. Sari Pediatri 2009; 11:167-73.

3. Donovan SM. Human milk: nutritional properties. Dalam: Duggan C, Watkins JB, Walker WA, penyunting. Nutrition in pediatrics. Edisi keempat. Shelton: Peoples Medical Publishing; 2009.h.341-62.

4. Lawrence RA. Host resistance factors and immunologic significance of human milk. Dalam: Breastfeeding. Edisi ketujuh. St. Louis: The Saunders: 2015.h.153-96.

5. Lawrence RM, Pane CA. Human breast milk: current concepts of immunologyand infectious diseases. Pediatr Adolesc Health Care 2007;37:7-36.

6. Riskesdas 2013. Riset Kesehatan Dasar 2013. Badan Penelitian dan Pengembangan Kesehatan Kementerian Kesehatan RI. Kementerian Kesehatan RI.

7. Subagyo B, Santoso NB. Diare akut. Dalam: Juffrie M. Soenarto SSY, Oswari H, Arief S, Rosalina I, Mulyani NS, penyunting. Buku Ajar Gastroenterologi Hepatologi. Edisi pertama. Jakarta: Badan Penerbit IDAI; 2010.h.87-120.

8. Benkerroum N. Antimicrobial activity of lysozyme with special relevance to milk. Afr. J. Biotechno 2007;7:4856-67

9. Sicairos NL, Soto FL, Lopes MR, Vargas DG, Pichardo CO, Garza M. Amoebicidal activity of milk, apo-lactoferrin, SIga and lysozyme. CM\&R 2006;4:106-13.

10. Maga EA, Desal PT, Welmer BC, Dao N, Kults D, Murray JD. Consumption of lysozyme-rich milk can alter microbial fecal populations. 2012 Jun 29. Diunduh pada 20 Desember 2012. Didapat dari: http://aem.asm.org/contentlearly/2012/06/04/ AEM.00956-12.full.pdf.

11. Ella EE, Ahmad AA, Umoh VJ, Ogala WN, Balogun TB, Musa A. Studies on the interaction between IgA, lactoferrin and lysozyme in the breastmilk of lactating women with sick and healthy babies. J Infect Dis Immun 2011;3:24-9.

12. Hassiotou F, Hepworth AR, Metzger P, dkk. Maternal and infant infections stimulate a rapid leukocyte response in breastmilk. Clin Trans Immunol 2013;2:1-11.

13. Hegar B dan Magdalena S. Air Susu Ibu dan kesehatan saluran cerna. 2009. Jakarta. Diunduh pada 2 November 2011. Didapat dari: http://www.idai.or.id/asilartikel. asp?q=20091029105942.

14. Alarcon ML, Vitalpando S, Fajardo A. Breast-feeding lowers the frequency and duration of acute respiratory infection and diarrhea in infants under six months of age. J Nutr 1997;127:436-43.

15. Howie PW, Forysth JS, Ogston SA, Clark A, Florey CV. Protective effect of breast feeding against infection. Brit Med J 1990;300:11-6.

16. Lamberti LM, Walker CL, Noiman A, Victora C, and Black R. Breastfeeding and the risk for diarrhea morbidity and mortality. BMC public health. 2011;11:515.

17. Kementerian Kesehatan Republik Indonesia. Profil kesehatan Indonesia tahun 2014. Jakarta: Kementerian Kesehatan RI, 2015.

18. Lawrence RA.Host resistance factors and immunologic significance of humanmilk. Dalam: Lawrence RA,penyunting. Breastfeeding:A Guide for the Medical Profession. Edisi ketujuh.Missouri: Elsevier Mosby;2011.h.153-89.

19. Arthur AM, Peters MDJ, Munn Z, Chu WH. Safe management of expressed breast milk (EBM). Diunduh pada 10 Juni 2017. Didapat dari: http://www.saxinstitute.org.au.

20. Lawrence RA. Biochemistry of human milk. Dalam: Breastfeeding. Edisi ketiga. St. Louis: The Mosby;1989.h.73-115.

21. Iskin A, Almog M, Peri R, Halasz K, Srugo I, Kessel A. Changes in immunomodulatory tituents of human milk in response to active infection in the nursing infant. Ped Res 2012;71:220-5.

22. Lonnerdal B. Nutritional and physiologic significance of human milk proteins. Am J Clin Nutr 2003;77:1537S-43S

23. Michaelsen KF. Breastfeeding. Dalam: Koletzko B, penyunting. Pediatric nutrition in practice. Edisi pertama. Basel: karger;2008.h.85-9. 